\title{
360. ディジタル画像処理フィルタのシミュレーション
}

\author{
Simulation of Filtration in Digital Image Processing
}

大分医科大学医学部附属病院 放射線部

○船越猛 ・山口 正孝・望月 祐次・ (Takeshi Funakoshi) (Masataka Yamaguchi) (Yuji Mochiduki)

山内 徹・高木 育也・城生朋頙

(Toru Yamauchi) (Ikuya Takagi) (Tomoaki Shiro)

【目的】画像処理において最適フィルタの決定は，観測系の信号・雑音特性を理解しなければならず，一般には 困難なことが多い。我々は種々の信号・雑音に対してどのフィル夕が有効かつ効果的に雑音除去・画像強調を 行えるか，パーソナルコンピュータを用いて1次元シミュレーションを行ったので報告する。

【方法】信号として矩形波, 三角波, ガウス分布型, 指数関数型, ローレンツ型, デルタ関数型, 等を, 雑音と して一様乱数, ガウス分布, ポアソン分布, ガンマ分布, 指数乱数を発生させ，そのヒストグラムと分布のモ一 メントを求める。

実空間処理フィルタとして多項式曲線近似手法のSavi tzky-Golay フィルタと突発性雑音の除去に用いられるメ ディアンフィルタを使用する。

周波数空間処理フィルタとしてButterworth filter,Hiener filterを使用する。

適正条件を決定する為に，処理結果と原信号との差の二乗和を求め評価基準とする。

一連の処理過程をFig. 1のフローチャートに示す。なおプログラミングにはMS-Cを使用した。

【結果】Fig. 2 にプログラムで発生させた乱数分布を示寸。Fig. 3 に矩形波信号と一様乱数雑音の一例を示す。 （左上：信号・雑音の合成，右上：雑音のパワースペクトル，右下：信号のパワースペクトルとフィルタ，左下： 処理結果）Fig. 4 以下に矩形波信号と一様乱数雑音の各フィルタ処理結果を示す。(棒：残差二乗和)

Savitzky-Golay フィルタは、平滑化点の数を増やしても残差二乗和は小さく成らず、7点 以上では信号レベル が下がる。メディアンフィルタも同様であるが、信号幅の 2 倍を超えると極端に信号レベルが下がる。

Butterworth filter や m-Wiener filter はパラメータが多くその決定には，信号・雑音のスペクトルに照らし 合わせ慎重に行わなければならない事が再確認出来た。

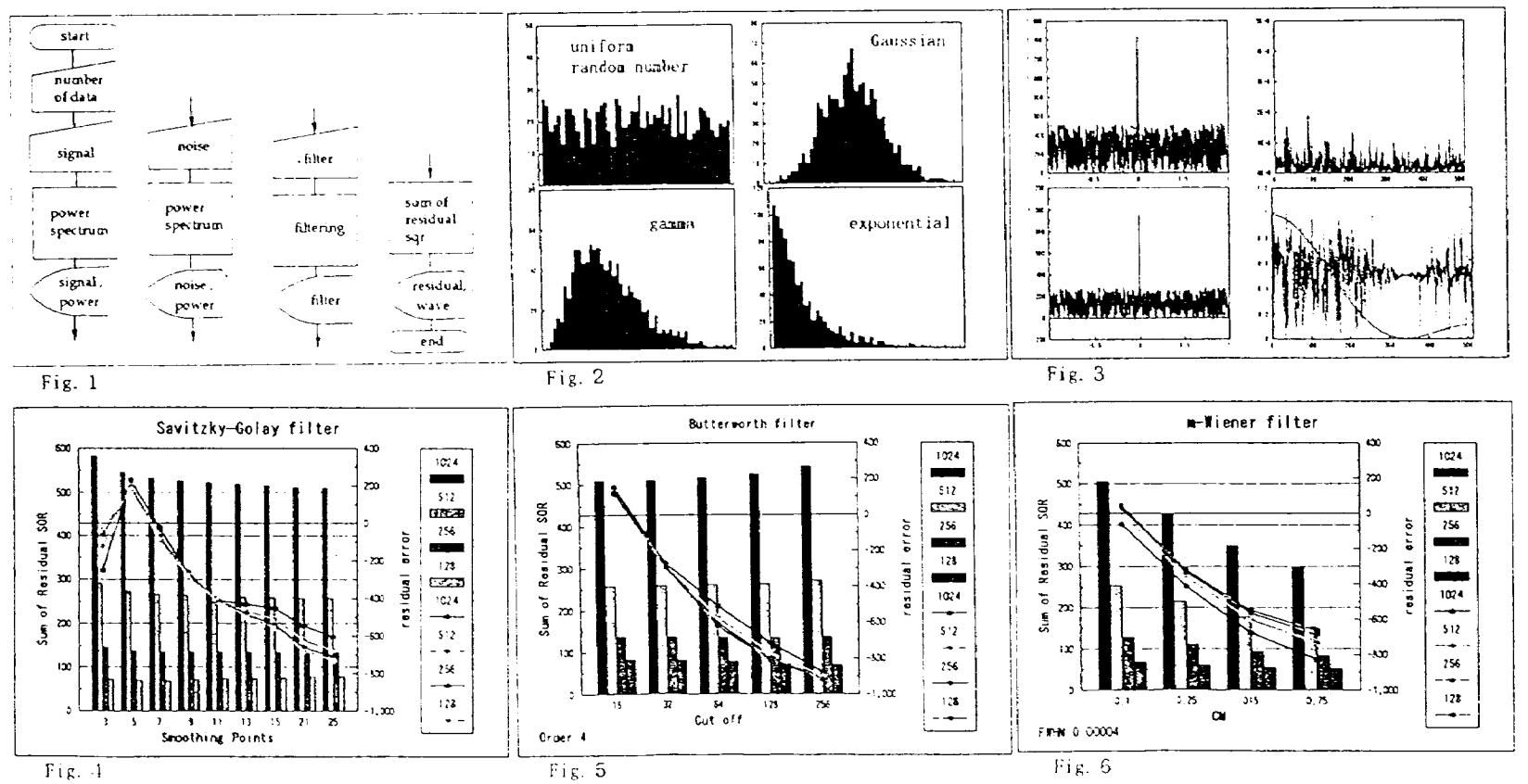

